\title{
Source Analysis of Post-Blasting Events Recorded in Deep Copper Mine, Poland
}

\author{
Alicja CAPuta ${ }^{1}$ and Łukasz Rudziński ${ }^{1}$
}

\begin{abstract}
Seismic and rock burst hazard is a very important factor that has to be considered in seismically active mining areas. Several different methods are used to decrease seismic activity in mines. Among others, an active prevention method known as destress blasting, is considered the most effective technique. The aim of this work is to find possible influences of such active prevention on observed seismic activity recorded in the established waiting time after blasts. Using technological knowledge and seismic data recorded by an underground seismic network, we estimated several parameters that characterize sources provoked by blasting works and compared them with the parameters obtained for spontaneous, non-provoked mining tremors. According to our studies the source mechanisms of post-blasting seismicity are characterized by the similar non-DC part of the full moment tensor whereas the source mechanisms of spontaneous events are not characterized by any specific features. On the other hand nonprovoked seismicity presents lowest values of apparent stress. Also $E_{S}$ to $E_{P}$ ratio suggest some differences between events occurred immediately after blasting (up to $30 \mathrm{~s}$ ) and the rest dataset. We believe that these parameters could be considered valuable tools supporting established safety time limitations after active prevention.
\end{abstract}

Key words: Destress blasting, focal mechanisms, source parameters, active prevention in mines.

\section{Introduction}

Legnica-Głogów Copper District (LGCD), Poland, is a mining area with three deep mines characterized by very high seismic activity. More than 2500 events above M0.8 (seismic energy E10 ${ }^{3} \mathrm{~J}$ ) are registered every year in the LGCD by local and regional seismic networks (Lasocki 2005; Rudziński

Electronic supplementary material The online version of this article (https://doi.org/10.1007/s00024-019-02171-x) contains supplementary material, which is available to authorized users.

1 Department of Seismology, Institute of Geophysics PAS, Ksiecia Janusza 64 str, 01-452 Warsaw, Poland. E-mail: acaputa@igf.edu.pl; rudzin@igf.edu.pl and Dineva 2017). All three mines (Lubin, Polkowice-Sieroszowice and Rudna-Fig. 1) exhibit high seismicity rates associated with rockbursts. These rockbursts include tunnel collapses, footwall uplift and/or sidewall failures. On average, 16 rockbursts were observed every year during the period 1990-2010 (Butra and Kudełko 2011). The last tragic rockburst occurred on Rudna mine in late November, 2016 and caused 8 fatalities, massive tunnels collapse and footwall uplift in the whole affected mining panel (Lasocki et al. 2017).

Due to tectonic and exploitation stresses, the majority of LGCD's mining panels are located in the zones with the highest level of rockburst hazard. To reduce the risks of rockburst, mining management has implemented several prevention methods divided into passive and active types. While passive prevention includes special designed room and pillars mining system with roof support, active prevention, among others, consists of destress blasting. The latter method is considered the most effective way to destress the rock mass in the vicinity of the mining faces. Additionally in Polish copper mines, the detonation of the explosive charge is used as a method of copper ore excavation.

The seismicity in the blasted panel is expected to increase for some time after the detonation, during a socalled 'waiting time'. It is a time period after the blasting operations are completed, in which all work activists are hold. Based on mining seismic catalogues, we can conclude that more than $30 \%$ of all mining events observed in the LGCD occurred during the waiting-time. These events in mining nomenclature are treated as provoked by the active prevention (Goszcz 1999). While the majority of provoked tremors are usually recorded within $2 \mathrm{~h}$ after detonation (Gogolewska and Biernat 2005), several events with $\mathrm{M}>2.5$ (some of them associated with rockbursts) 
have even occurred more than $6 \mathrm{~h}$ after the blasting works (Kłeczek 2004). These events are often observed especially after torpedo blasting in the tunnel roof. For these kind of blastings the amount of explosives is up to two times higher than during winning blasting. Currently, the analysis of cumulative energy released during established waiting time is used to quantify the effectiveness of the stress reduction during active prevention. This approach is commonly used and has been described by many authors, e.g. Hinzen (1998); Sanchidrián et al. (2007) and Konicek et al. (2013). On the other hand, there is no direct seismological evidence that the physical processes for events triggered by blasting are similar or different from seismicity occurring spontaneously beyond the established timing criteria. The current stage on this area is still challenging (Konicek et al. 2013; Caputa et al. 2015; Wojtecki et al. 2016, 2017) and is essential for improving exploitation under high seismic hazard conditions in different mining environments.

In this paper, we focus on two different groups of mining seismicity provoked and non-provoked events, recorded with an underground recording system belonging to Rudna mine. Since there are no direct scientific evidences that seismicity observed just after active prevention is connected with blasting works, we tried to find possible characteristic features of seismicity induced by explosive charge detonations in deep mines. The results obtained in this study shed some light on this important issue. Investigating the source mechanisms of these seismic events and their spectral source parameters we would like to extend the previous studies based only on moment tensor inversion analysis of post-blasting seismic records (Caputa et al. 2015). The current study is a next step towards understanding the influence of active prevention on the observed seismic activity.

\section{Site Description}

The LGCD district is located in south-western Poland and it's an important mining area (Fig. 1). The geological resources are estimated at 1.7 billion tons of copper ore with $1.84 \%$ average $\mathrm{Cu}$ content (acc. http://www.kghm.com accessed January 13, 2019). The stratoidal type copper deposit on the Foresudetic Monocline is characterized by small

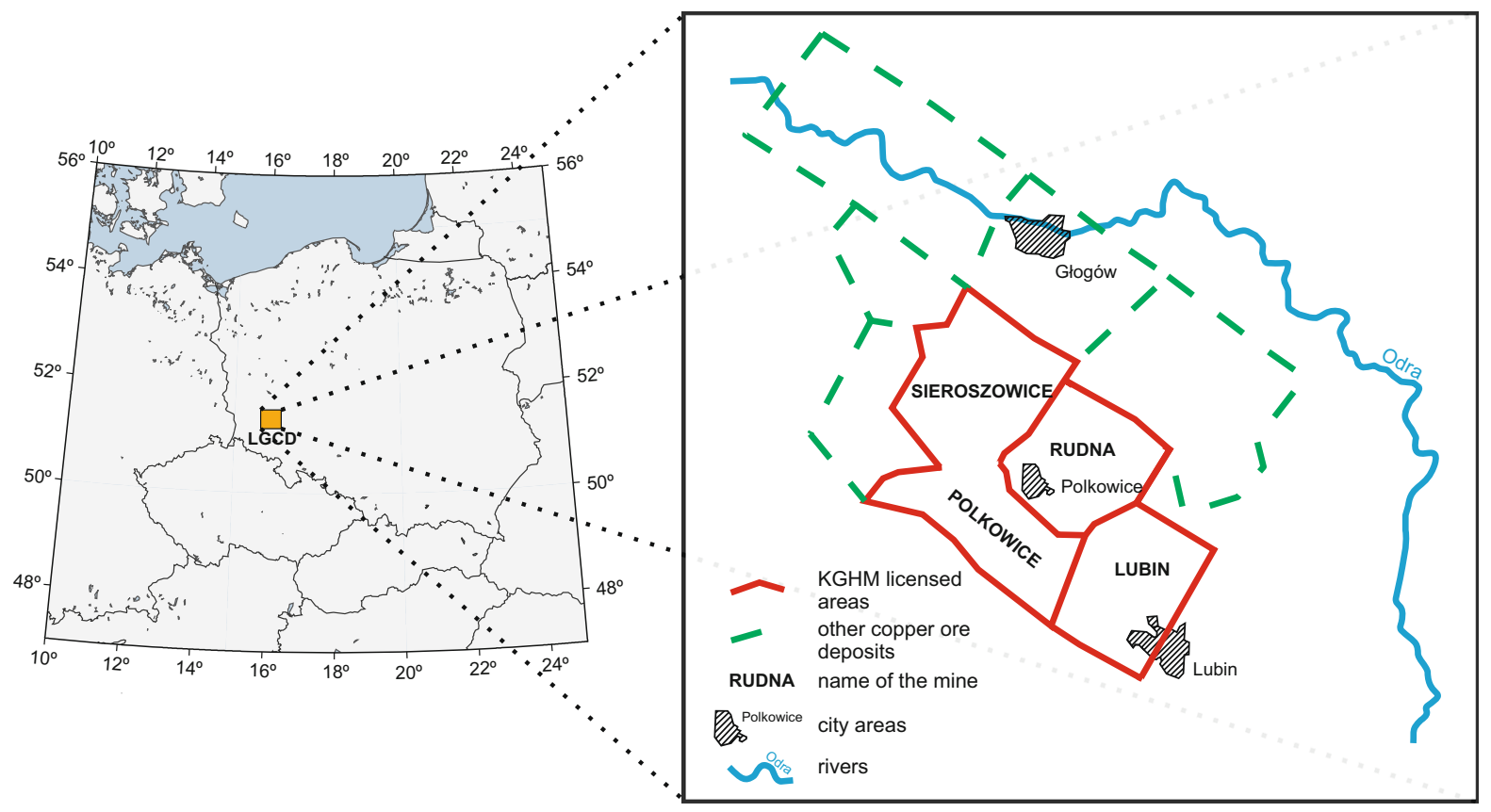

Figure 1

Location of the LGCD area with three copper mines: Lubin, Polkowice-Sieroszowice and Rudna 


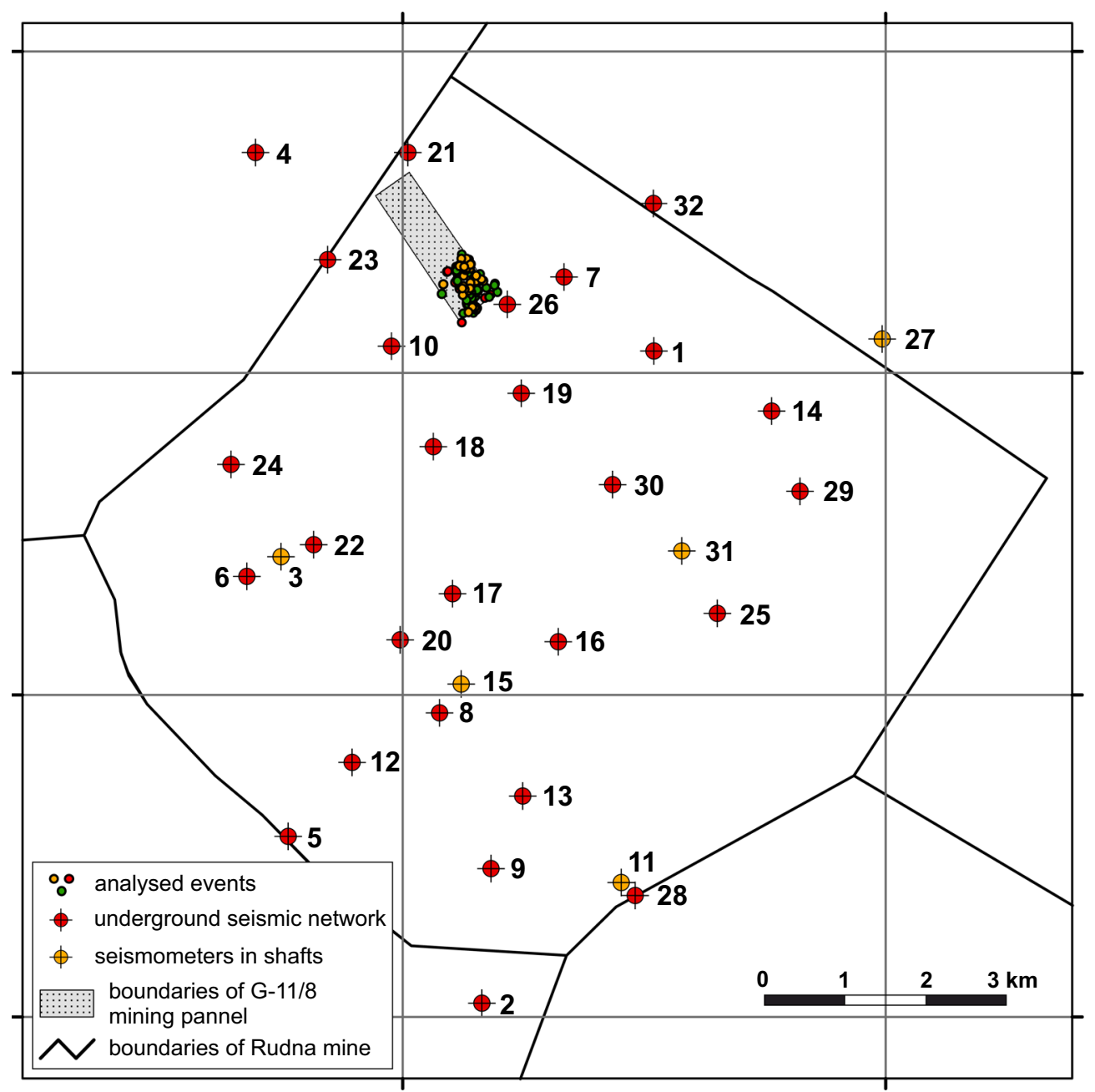

Figure 2

The sketch of Rudna mine seismic network and seismic events occurred in panel G-11/8

inclination (approximately $4^{\circ}$ towards the NE) and variable thickness (from 0.4 to $26 \mathrm{~m}$ ). Varying lithological profiles contain Rotliegend sandstones in the floor of the copper ore strata, a thin strata of ore shales $(\sim 0.4 \mathrm{~m})$ and dolomites or limestones of the Wera cyclothem in the upper part and above the extraction level. Because of the diversity in the ore body hardness (from 15 to $170 \mathrm{MPa}$ ), blasting on the mining front is the only method in Polish mines, to obtain the copper ore. The ore mineralization can be found at depths between 600 and $1200 \mathrm{~m}$ below the surface (Goszcz 1999). Exploitation in the mines is carried out by winning blasting in several mining panels using a room-and-pillars mining system. This paper addresses the data recorded on the G-11/8 mining panel, which is located in the north-western part of the Rudna mine (Fig. 2).

\section{Blasting Work Characterization on the G-11/8 Mining Panel}

In Polish copper mines several types of blasting are applied, such as group winning blasting, destress blasting in sidewalls, and torpedo blasting in the floor, pillars and roof (Gogolewska and Biernat 2005). During active prevention combined with extraction what is carried out using group winning 
blasting, the explosive charges are detonated simultaneously in blast holes located in several mining faces. Such practice destructs ore-bearing rocks and changes the state of stress in the nearest rocks. This can be responsible for tremors and in this way decrease the seismic hazard in the blasted panel. Due to the complexity of the ore deposit, depth of the excavation and geomechanical conditions of the mining strata, the northern part of the Rudna mine, where the G-11/8 mining panel is located, is seismically hazardous. To minimize seismic and rockburst hazard and to excavate the copper ore in the G-11/8 section, a modified method of group winning blasting with elongated blastholes has been developed (Fig. 3). First, the ore was exploited via daily detonations of explosive charges in short breaking-in holes (several meters long, depending on local mining and geological conditions; approximately $3 \mathrm{~m}$ on the G-11/8 panel). Usually, a maximum of 30 short boreholes were drilled on one mine face with a maximum of $4 \mathrm{~kg}$ of explosive charge per borehole. During the active prevention, additional long and large diameter holes (10-12 m long, Ø $127 \mathrm{~mm}$ ) were drilled in the middle of the mine face and filled with $40-50 \mathrm{~kg}$ of explosive charge (Dubiński and Konopko 2000). The winning blasting with elongated blastholes on the G-11/8 section had been performed simultaneously in 5 mine faces. Another kind of prevention blasts were explosions in the solid, pillars and in the floor. Detonation of the explosive charge in solid and pillars are common practise in polish copper mines to decrease the stresses accumulated in the vicinity of the mining face and in supporting pillars. This kind of works were conducted by detonation of small charges ( $\max 3$ kilos per hole) in $3 \mathrm{~m}$ blastholes with diameters of 48 or $64 \mathrm{~mm}$. Prevention blasts in the floor were performed less frequently than other prevention blastings due to the specific geomechanical condition of excavated ore-bearing rocks. Sandstone floor rocks have lower capacity to accumulate elastic energy than carbonate roof rocks. For these reasons destressing detonations were made using short boreholes $(1.5 \mathrm{~m})$ with diameters of 40 or $50 \mathrm{~mm}$ drilled in the floor, at an angle of $60^{\circ}$ to $70^{\circ}$ (Gogolewska 2010). The last and the least-used method within the prevention in G-11/8 panel was torpedo blasting in the roof. These kind of blasting works consisted of drilling long boreholes in the roof rocks in the area of mining face or over the solid and detonate a big amount of explosives (up to several hundred kilos per one borehole) (Dubiński and Konopko 2000). This method was used once every 3 months and led to destressing hard and thick carbonate roof rocks which are characterized by high stress accumulation capacity. Other prevention methods were used at least, once a week and winning blasting were conducted every day.

Blasting works in Rudna mine are conducted between working shifts and with established waiting time. Waiting time is established individually for different mining panels depending on specific geological and mining conditions, distance from the blasting site as well as on blastings type. It can vary from $30 \mathrm{~min}$ for the mining panels of the lowest rockburst hazard and low charge detonations (Butra and Kudełko 2011) to even $24 \mathrm{~h}$ in a blasting area of the highest rockburst hazard zones. After blasting, the waiting time for the entire G-11/8 section was also

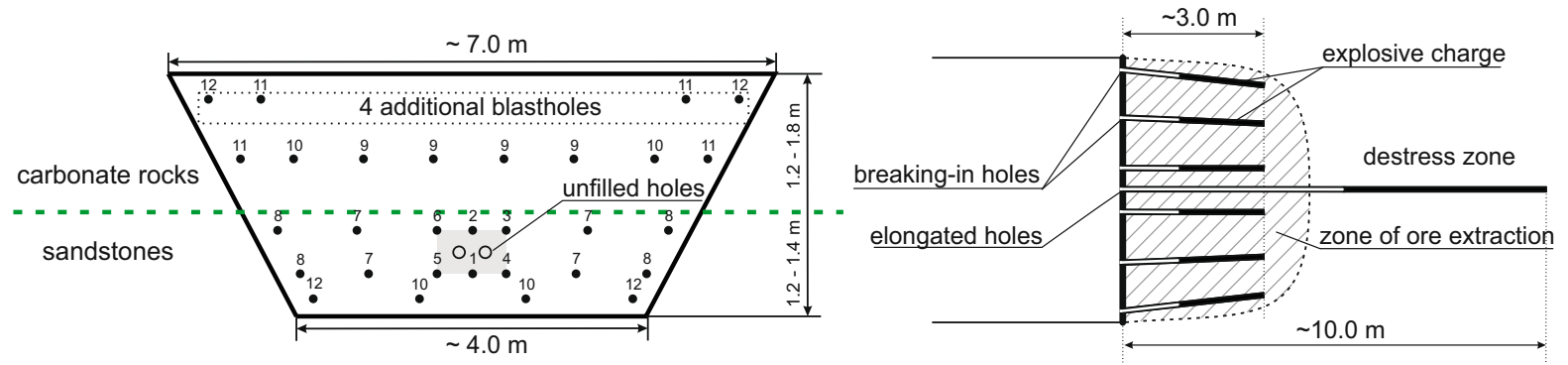

Figure 3

Sketches of the blasting works developed for panel G-11/8 
established. At distances up to $150 \mathrm{~m}$ from the blasting site, the time was $1 \mathrm{~h} 30 \mathrm{~min}$ while for the site with high rockburst hazard, the waiting time was extended to $24 \mathrm{~h}$. It is worth to mention here, that the last of the waiting time was rather arbitrary chosen without any supports from scientific results.

\section{Data Description}

Induced seismicity in Rudna mine is observed via an underground local seismic network (Fig. 2) that consists of 32 vertical Willmore III seismometers $(1-100 \mathrm{~Hz})$ located at the excavation level or in the middle depth of the mining shafts. The depth of the sensors vary from 650 to $1150 \mathrm{~m}$. Five sensors are located on the shafts approximately $300 \mathrm{~m}$ below the surface. Signals are recorded with a sampling rate of $500 \mathrm{sps}$. The relatively low dynamic range (less than $66 \mathrm{~dB}$ ) causes signals clipping in the case of a strong seismic tremor (Koziarz and Szłapka 2010; Rudziński et al. 2017). The network is able locate seismic events with high precision, i.e., a resolution of less than $100 \mathrm{~m}$ horizontally and approximately $300 \mathrm{~m}$ vertically (Rudziński and Dębski 2011).

In mining panel G-11/8 the deposit was exploited from the beginning of the XXI century to the end of 2014. During this period, 29,135 tremors were recorded, and 329 of them were classified as high energy seismic events $\left(E>10^{5} \mathrm{~J}, \mathrm{M}>2.0\right)$. In this study, we use data for the tremors occurred between 2011 and 2014. The catalogue for this time includes 18,098 events but in our study we looked for events with energy greater than $10^{5} \mathrm{~J}$. Finally, our database contained 51 tremors classified as post-blasting events that took place during the waiting time after active prevention, and the rest (50 quakes) were considered as non-provoked by any blasting works and occurred spontaneously (beyond the waiting time). Presented classification was based on the mining catalogs which include origin time, location, energy of events as well as information about the reference time corresponding to detonations done in selected mining panel. The total database contained 101 tremors with energy from $1.1 \times 10^{5}$ to $3.2 \times 10^{7}$ $\mathrm{J}$, which corresponds to energy magnitudes $1.45<\mathrm{M}_{\mathrm{e}}<3.3$ (Rudziński and Dineva 2017).
The source locations of the events were obtained with high precision with average errors of epicentral coordinates less than $100 \mathrm{~m}$. The depth estimates had higher uncertainties of more than $300 \mathrm{~m}$.

\section{Methods and Results}

\subsection{Focal Mechanisms Analysis}

The focal mechanisms for each event was estimated using manually picked P-wave onsets on all 32 sensors using amplitude inversion in the time domain. Since mining induced tremors are often characterized by significant non-double-couple (nonDC) components (e.g., Dreger et al. 2008; Rudziński et al. 2016), we decided to estimate a full moment tensor (MT) instead of a simple DC source model. A full MT can be further decomposed into isotropic (ISO) and deviatoric parts (Jost and Herrmann 1989). The isotropic part of the full MT reflects the volume changes in the source while the deviatoric component can be further split into a compensated linear vector dipole (CLVD), corresponding to uniaxial compression or tension and a DC, which indicates a pure shear motion in the source on one of the possible fault planes. This decomposition is often used in mining seismology (Hasegawa et al. 1989). The full MT solutions were estimated using the FOCI MT software (Kwiatek et al. 2016). The procedure used seismograms in the time domain and amplitudes for P-waves onsets, recorded by the underground Rudna mine seismic network (Fig. 2). The estimations were performed with the settings and velocity model already tested for the local Rudna mine seismicity (e.g., Król 1998; Lizurek and Wiejacz 2011; Caputa et al. 2015; Lizurek et al. 2015). Since the catalogue is characterized by a relatively low depth accuracy (Rudziński and Dębski 2011), the parameter was corrected during inversion to obtain the smallest misfit.

We analysed 101 seismic events that occurred in panel G-11/8 and had energies greater than $10^{5} \mathrm{~J}$ (Fig. 4a, b). The whole dataset was divided into two groups. The first group (I in Fig. 5) consists of the provoked events that occurred during the waiting time, while the second group (II in Fig. 5) contains 

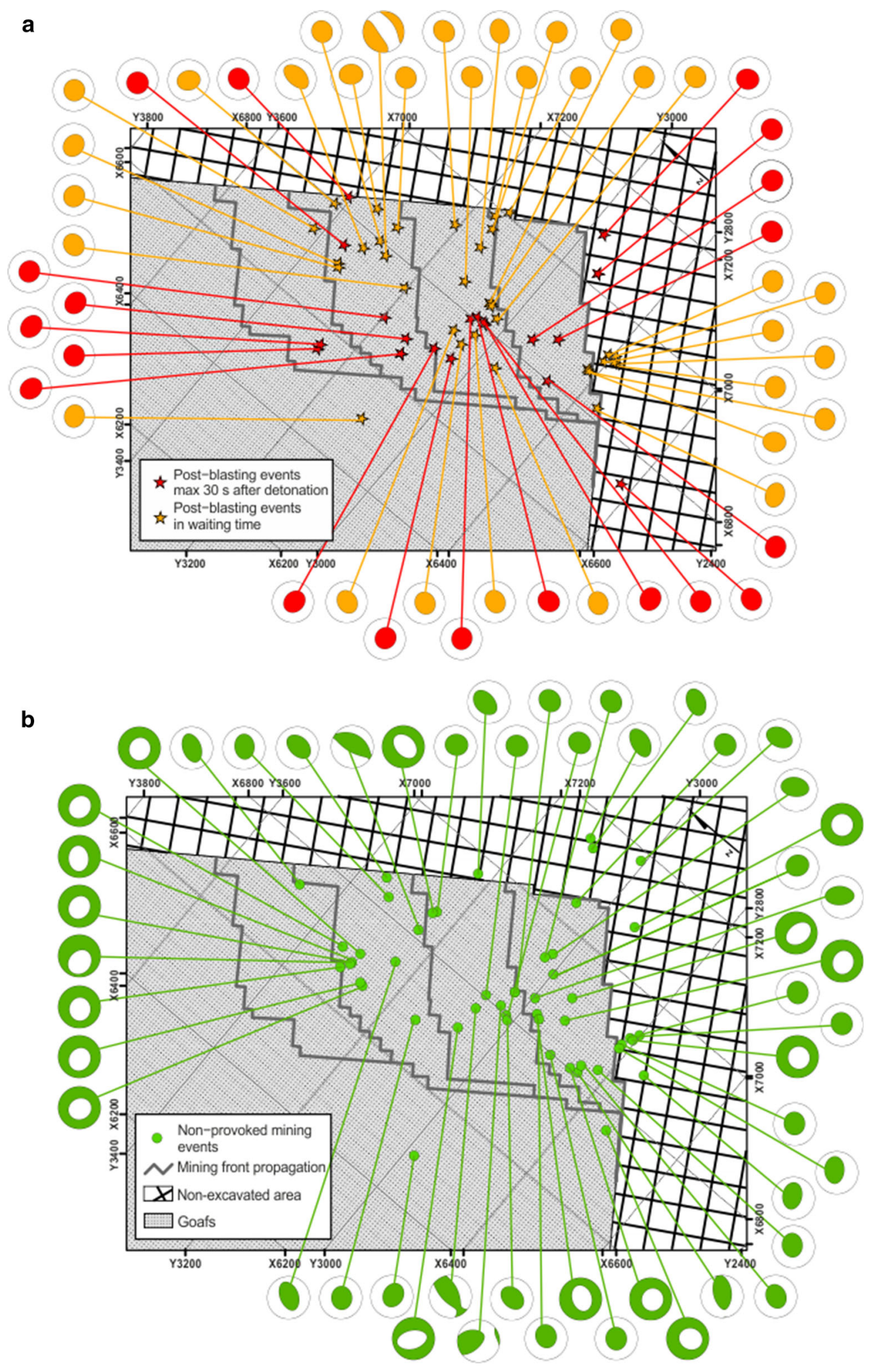
Figure 4

Area of copper ore exploitation in the G-11/8 mining panel with locations and MT solutions of analysed events. a Locations and MT solutions of post-blasting seismicity, b locations and MT solutions of non-provoked seismicity. The map was prepared in the PL-2000 coordinate system

the rest of events that happened spontaneously besides the established time period. Group I is subdivided into two sub-parts: the events recorded up to $30 \mathrm{~s}$ after the detonation (IA in Fig. 5) and subgroup IB (IB in Fig. 5) with events registered during the waiting time after the blasting. In this paper, the time criteria were taken directly from mining experience for panel G-11/8.
Group IA contains 19 tremors with energies between $1.2 \times 10^{5}$ and $3.7 \times 10^{6} \mathrm{~J}$. Eleven of them were recorded at the moment of detonation (marked in the seismic catalogue as $0 \mathrm{~s}$ after detonation). Group IB consists of 32 events (energy $1.0 \times 10^{5}$ to $1.9 \times 10^{7} \mathrm{~J}$ ) that occurred at different times from 9 to $1220 \mathrm{~min}$ after detonation. The first interesting features are similar focal mechanisms of post-blasting sources (Fig. 4), which are dominated by positive ISO and CLVD parts of the full MT for all sources in group I (Fig. 5). Let us now consider the full MT decomposition assuming that $100 \%$ is equal to 1 . The average ISO component for group $\mathrm{I}$ is $0.21 \pm 0.09$ while CLVD is $0.61 \pm 0.13$. The average DC part is smaller in this group at $0.19 \pm 0.13$. The existence of the volumetric changes in the sources is even more

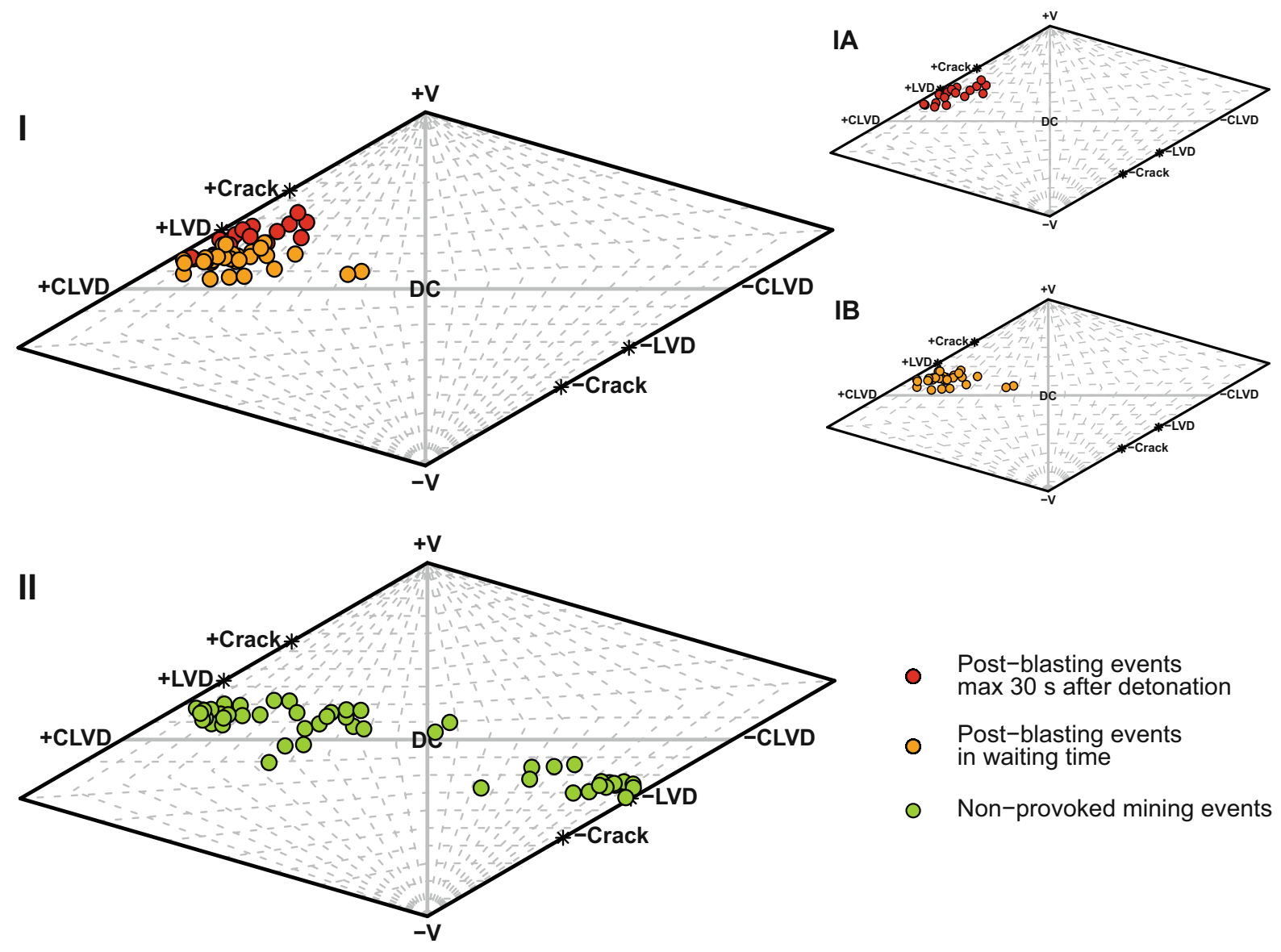

Figure 5

Source type Hudson plots (Hudson et al. 1989) for events within groups I (provoked tremors) and II (non-provoked events). Details concerning sub-groups IA and IB can be found in the text 

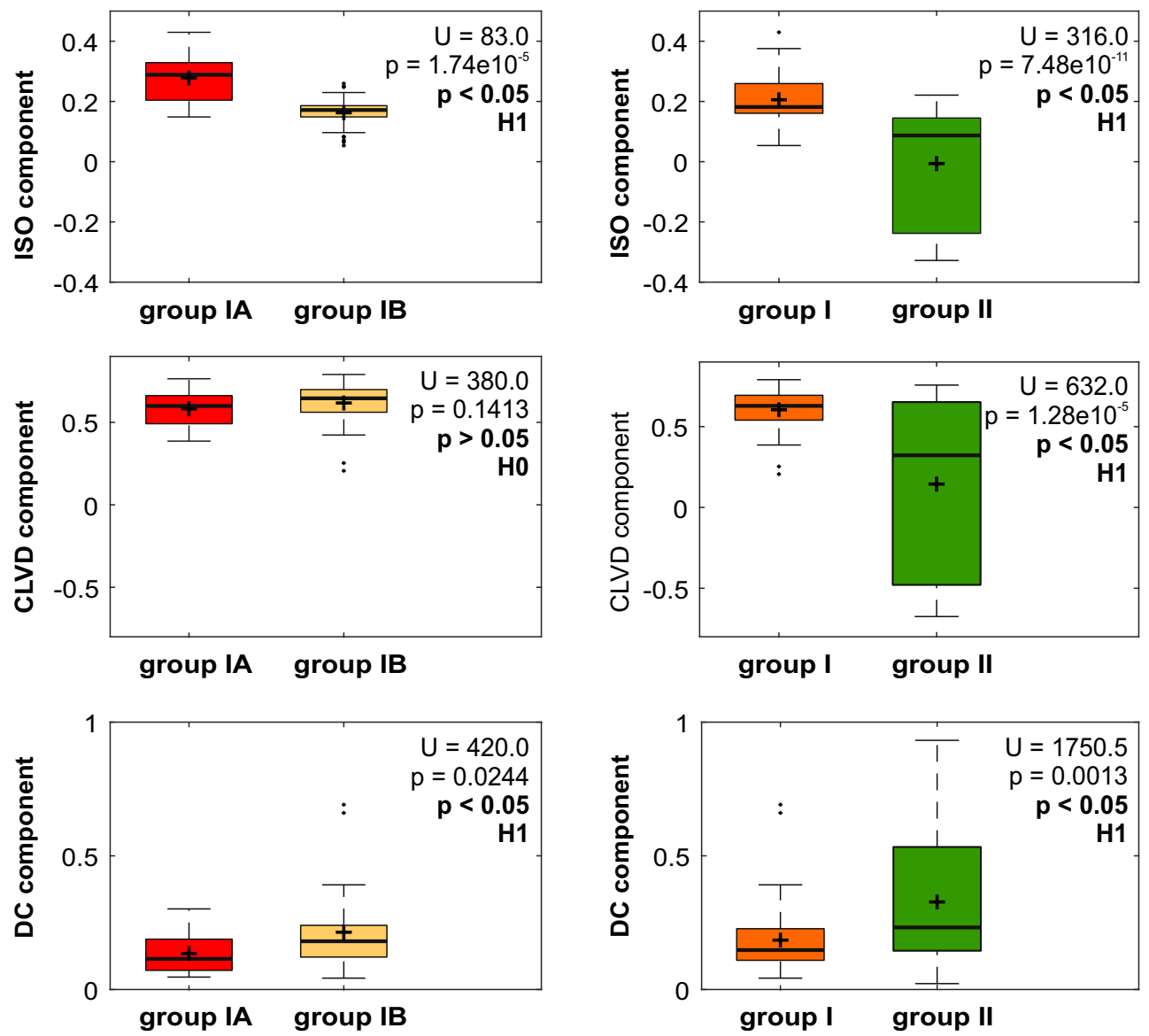

Figure 6

Results of Mann-Whitney U test of MT decomposition components calculated for selected groups of events. Mann-Whitney test is nonparametric test where H0 (null hypothesis): the two populations are equal versus H1(alternative hypothesis): the two populations are not equal. $U$ value is Mann-Whitney test variable, $p$ is statistical significance value which could be $p>0.05$ (what indicates a failure to reject the null hypothesis at the $5 \%$ significance level) or $\mathrm{p}<0.05$ (what indicates a rejection of the null hypothesis). The median values are marked as black bold lines, the mean values are marked as “+”. The bottom and top edges of each box indicate the 25 th and 75 th percentiles, the whiskers represent extreme data

visible when the two sub-groups IA and IB are considered. For sub-group IA, the ISO part is on average $0.29 \pm 0.08$ and for sub-group IB, the ISO part is lower: $0.16 \pm 0.05$. To examine whether the values of different groups are statistically different we have decided to apply a Mann-Whitney U test (Hollander and Wolfe 1973). It's a non-parametric test which allows to compare samples of the same population but of different sizes. According to applied statistical test, isotropic part of MT decomposition of sub-group IA is statistically different from ISO of sub-group IB (Fig. 6). The average CLVD has the highest values for both sub-groups: $0.58 \pm 0.11$ for IA and $0.62 \pm 0.13$ for IB, which are similar to each other (Fig. 6). In case of DC component, its average in IA is only $0.14 \pm 0.07$, and this value is statistically significant and higher than DC of subgroup IB which is $0.22 \pm 0.15$ (Fig. 6). The abovementioned results suggest direct influence of the detonation on seismic sources registered close in time to the blasting works. The explosive parts of sources could be connected with rock fracturing due to explosion. Although such sources are characterized with a significant isotropic component, other reasons are not excluded since the seismic processes are associated with the new stress state in the vicinity of 

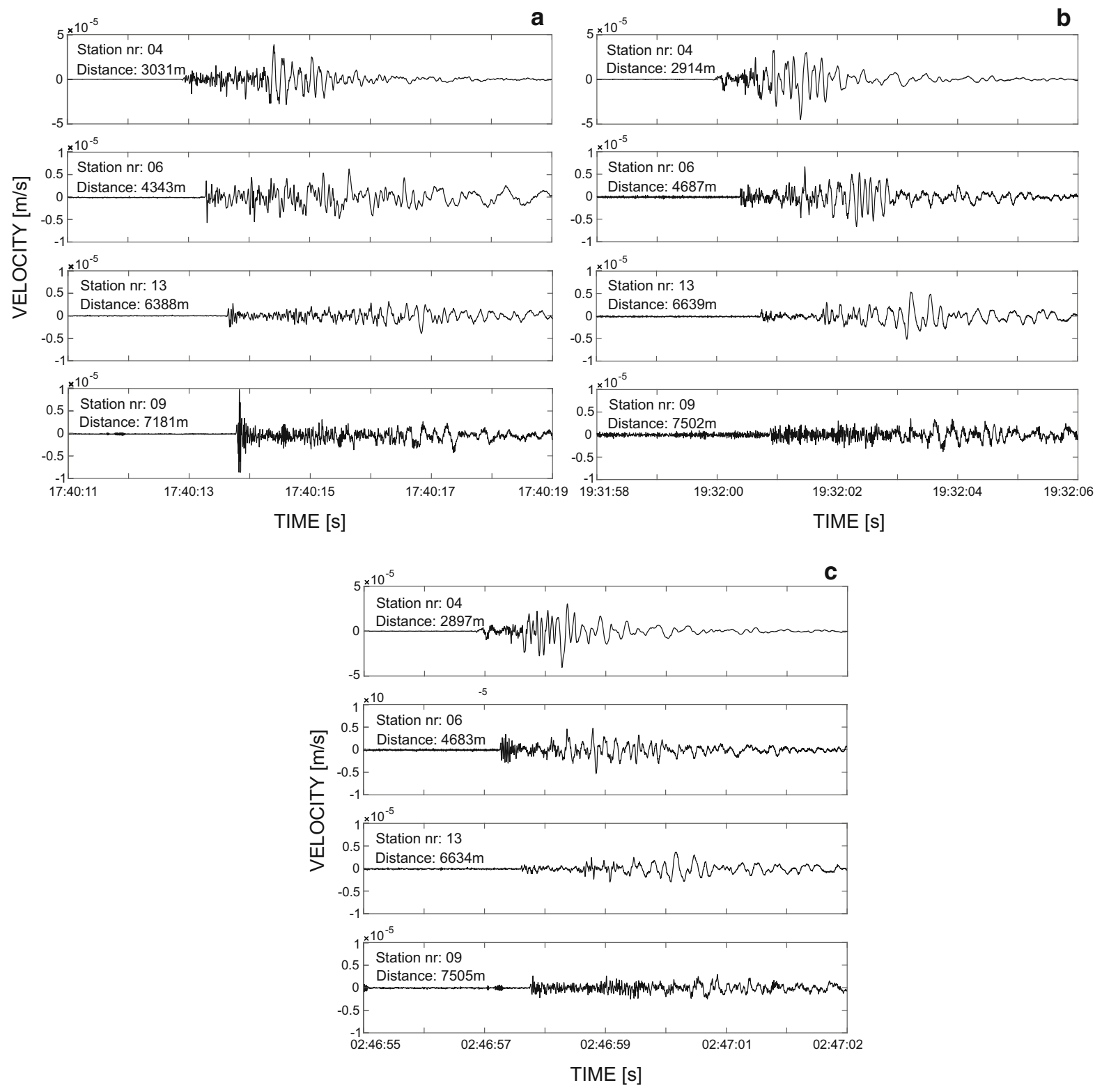

Figure 7

Examples of seismograms used in this study: a event recorded in Jan 2012 occurred in the moment of explosive charge detonation (subgroup IA; event number 10 in electronical supplement Table_ES1); b event recorded in Mar 2011 occurred $1 \mathrm{~h}$ and 41 min after blasting (subgroup IB event number 22 in electronical supplement Table_ES1); c non-provoked, spontaneous event recorded in Feb 2011(event number 55 in electronical supplement Table_ES1)

the blasted area (Wojtecki et al. 2017). This observation is supported by the lower ISO values visible in sub-group IB. Nevertheless, events in the first group are characterized by high contribution of non-DC forces and represent strong source dilatation. Such focal mechanisms could be caused by the horizontal crack opening or cavity collapses (Hasegawa et al. 1989). Since only 2 of the investigated post-blasting events had been associated with observed consequences, like rockburst or roof and pillars support damages, we are inclined to the hypothesis of crack opening sources. This explanation could be supported 

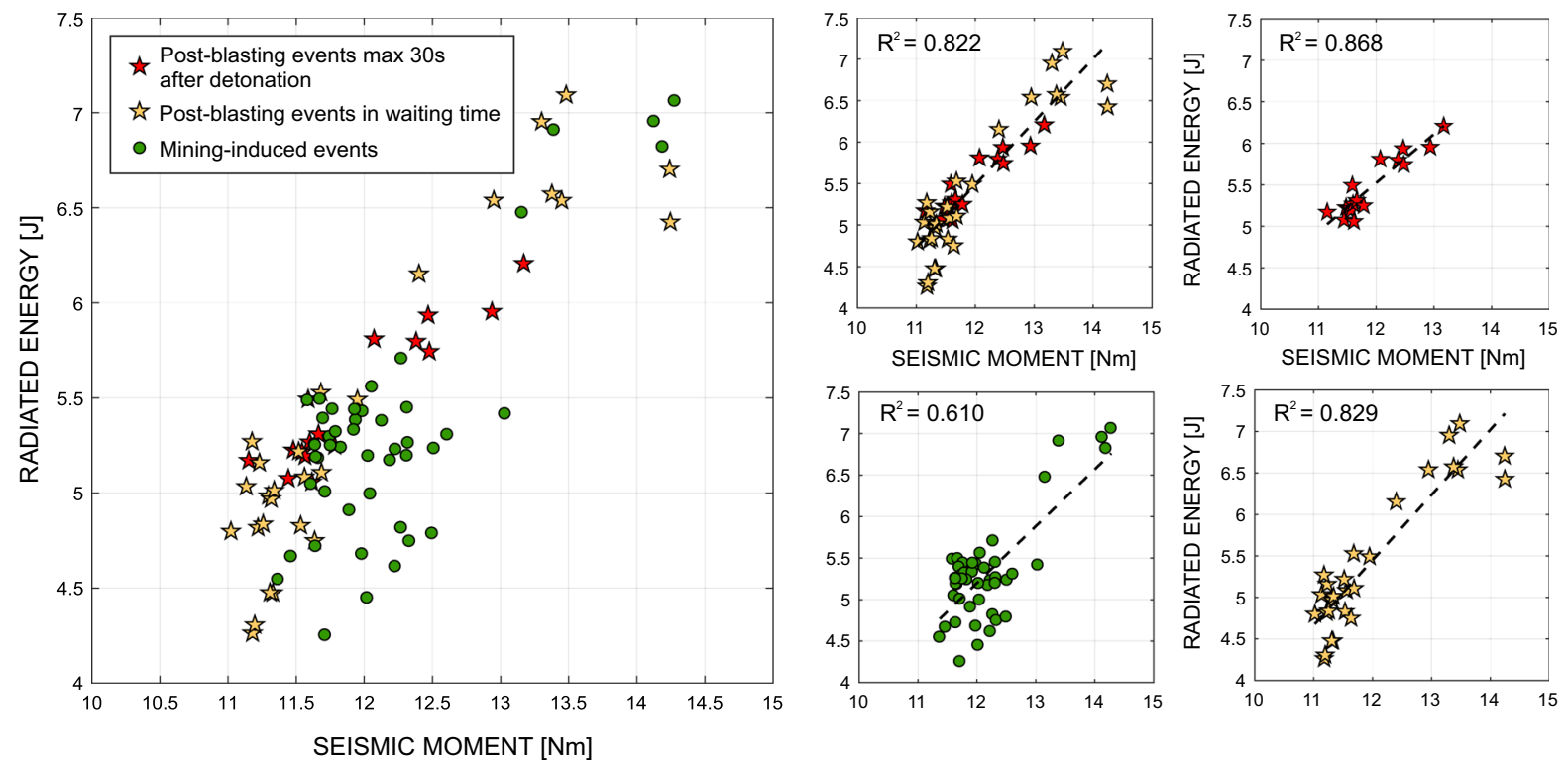

Figure 8

Radiated energy as a function of the seismic moment. Black dashed lines in right sub-plots represent least-squares fitting. All figures present logarithmic values of the analysed parameters

by layered roof rocks which under stress changes caused by exploitation could stratify their structure (Gogolewska and Michalak 2009; Waczur and Zaczek 2004).

The events in group II are 'common' spontaneous events with energy between $1.1 \times 10^{5}$ and $3.2 \times 10^{7}$ J. Their sources are characterized by various types of mechanisms (Fig. 4) and we cannot find any kind of similarity in the full MT components. However, the most interesting feature of this group is that mean value of DC component is significantly greater than for group I (Fig. 6) with respect to all analysed events. The average DC for this group is $0.33 \pm 0.23$ but we also have to highlight that results of decomposition in case of group II are strongly scattered for DC as well as for ISO and CLVD. Sources of higher and positive CLVD component could be caused by stratify roof rock structure due to rockmass stress changes under exploitation. Nevertheless strong contribution of negative non-DC part is also observed in some of the spontaneous events. Under mining conditions it could be explained by pillars cracks. In the group of non-provoked events, as opposed to group I, double couple sources are also observed. Induced mining events with strong DC forces contribution could be caused by small faults reactivation or shear motion on discontinuities due to stress changes in the vicinity of extraction area. This observation suggests that the events are rather associated with very local geologic/tectonic settings and actually could be considered spontaneous or, in other words, non-expected/non-provoked events.

\subsection{Source Parameters of Mining-Induced Events}

Most seismic source theories based on kinematic or quasidynamic dislocation models predict that the far-field displacement spectrum should remain constant at low frequencies and become inversely proportional to some power of the frequency at higher frequencies (Madariaga and Ruiz 2016). While the spectrum is constant and proportional to the seismic moment at low frequencies, this spectrum begins to decrease at a certain value of the corner frequency $\left(f_{c}\right)$, which is inversely proportional to the size of the source. This division of the spectrum leads to two independent components: the low-frequency spectral level $(\Omega)$ and the corner frequency, which are obtained by the intersection of the high- and lowfrequency asymptotes of the spectrum. A procedure 

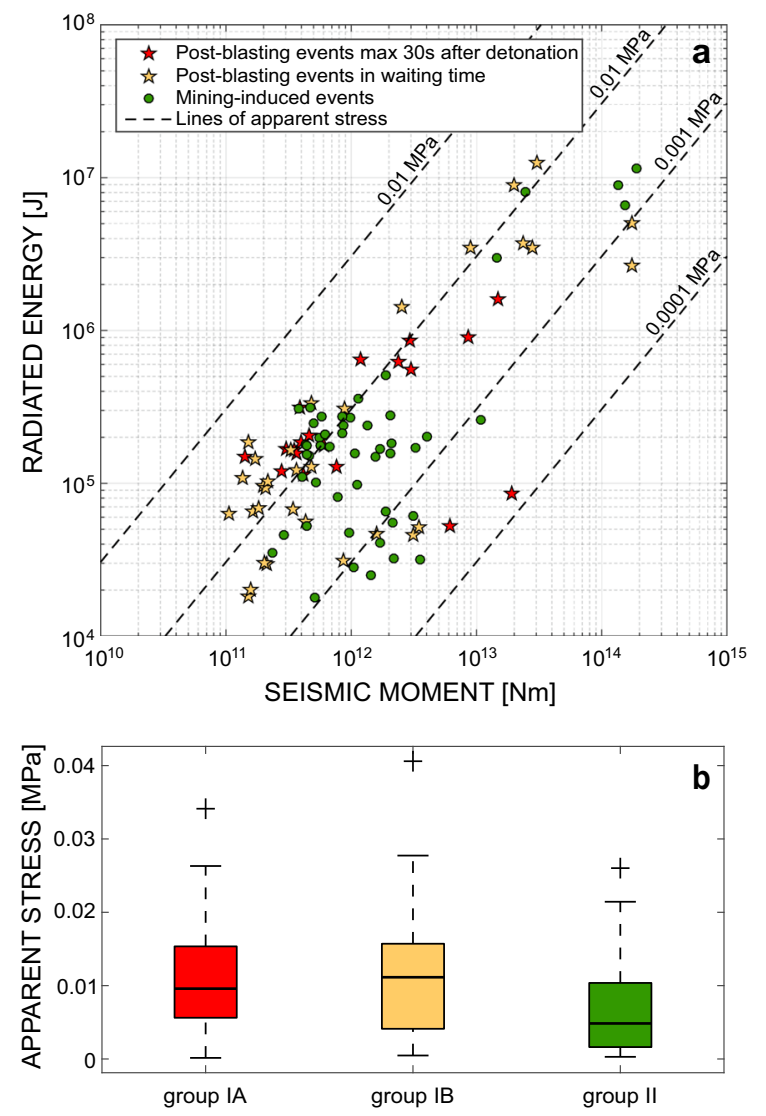

Figure 9

a Radiated energy as a function of seismic moment and apparent stress; b boxplot of median values (black bold lines) of $\sigma_{\mathrm{a}}$ calculated for selected groups of events. The bottom and top edges of each box indicate the 25 th and 75 th percentiles, respectively, the whiskers represent extreme data and the outliers are marked as "+"

based on the inspection of seismograms in the frequency domain is often used in mining seismology for estimating the source parameters although, not for blasting effects (Wojtecki et al. 2017). In this study, spectral analysis was applied to estimate the source parameters: scalar seismic moment, seismic energy, source radius, stress drop and apparent stress. The scalar seismic moment for each event was calculated upon the Boore and Boatwright (1984) assumption of low frequency spectral level $\Omega$, while the corresponding moment magnitude $\mathrm{M}_{\mathrm{w}}$ was obtained according to Hanks and Kanamori (1979). The seismic energy was calculated with the Boatwright and Fletcher (1984) relation between the radiated energy of P- and S-waves and the energy flux
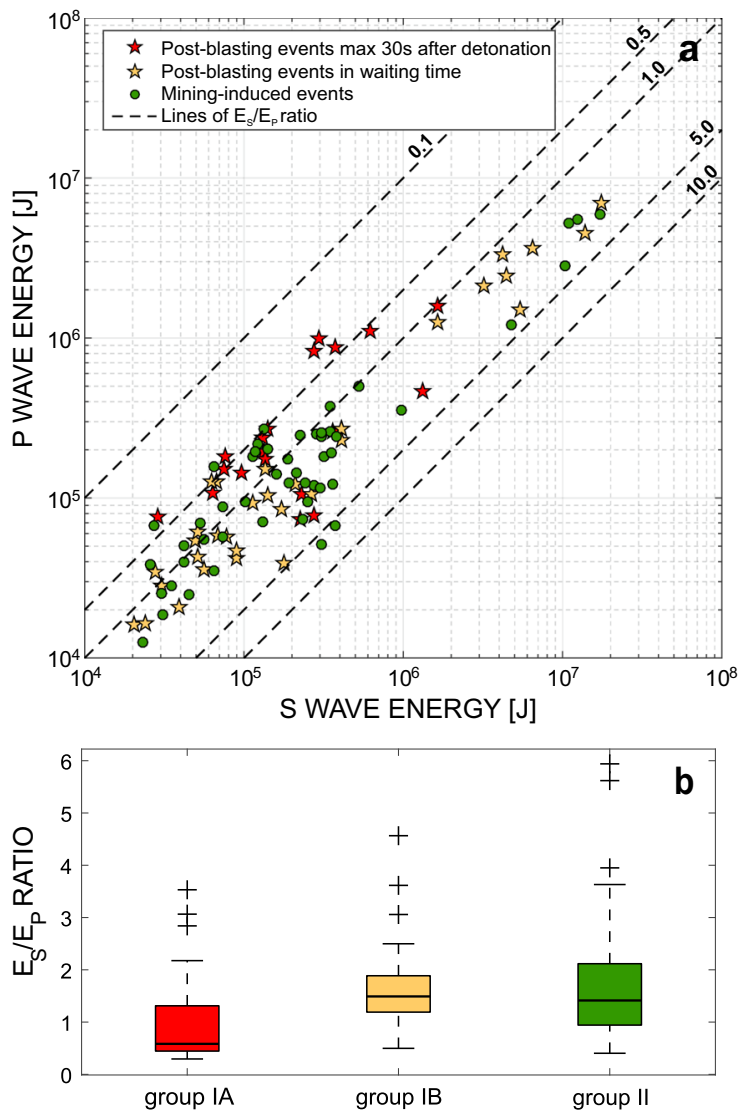

Figure 10

a P-wave energy $\left(E_{P}\right)$ versus $S$-wave energy $\left(E_{S}\right)$, b boxplot of median values (black bold lines) of $E_{S} / E_{P}$ ratios calculated for selected groups of events. The bottom and top edges of each box indicate the 25 th and 75 th percentiles, respectively, the whiskers represent extreme data and the outliers are marked as "+"

contained in the $\mathrm{P}$ - and S-wave signals in frequency domain. The source radius was calculated according to the Brune $(1970,1971)$ formalism with the use of the Madariaga (1976) circular fault model, which provides reasonable results in good agreement with in-mine observations (Gibowicz and Kijko 1994; Domański and Gibowicz 2008). The same model was used to estimate the stress drop. To calculate source parameters, we used signals with time windows limited to P- and S-wave trains. Only unclipped seismograms (Fig. 7 and in electronical supplements ESM_1.pdf) for all 101 events were used. To estimate source parameters we've used the following values: $P$ wave velocity $\alpha=5700 \mathrm{~m} / \mathrm{s}, \quad S$ wave velocity $\beta=3360 \mathrm{~m} / \mathrm{s}$, density $\rho=2900 \mathrm{~kg} / \mathrm{m}^{3}$ and rigidity modulus $\mu=32.74 \mathrm{GPa}$. The instrumental response 

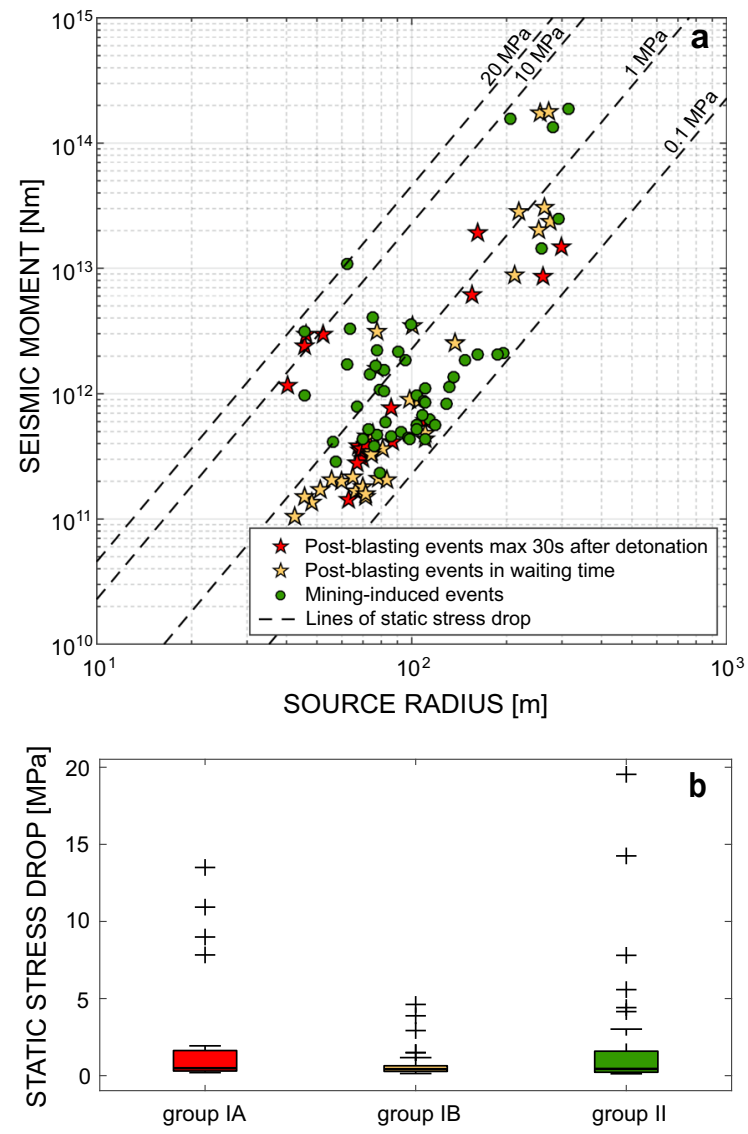

Figure 11

a Source radius versus seismic moment with static stress drops lines for each groups of events. b Boxplot of median values of $\Delta \sigma$ calculated for selected groups of events. The bottom and top edges of each box indicate the 25 th and 75 th percentiles, respectively, the whiskers represent extreme data, and the outliers are marked as “+”

and signal integration were used to obtain the real displacement records. Then, the time signals were tapered and the displacement spectra were calculated by the Fast Fourier Transform (FFT) technique with constant $Q_{P}=400$ for P-waves and $Q_{S}=200$ for $\mathrm{S}$-waves. All obtained results are presented in electronical supplement Table_SE1 and in Figs. 8, 9, 10, and 11 as a comparison between static and dynamic source parameters: seismic moment $\left(\mathrm{M}_{0}\right)$, radiated energy $\left(E_{R}\right)$, apparent stress $\left(\sigma_{a}\right)$, static stress drop $(\Delta \sigma)$, and source radius $(\mathrm{R})$.

Figure 8 shows the relation between $M_{0}$ and $E_{R}$, parameters describing the size/strength of the seismic source. For each group of data group I sub-group IA, and sub-group IB and group II we tried to find correlations among parameters using the leastsquares method. Linear regression was conducted for logarithmic data, and the results are presented in Table 1. The estimates were based on 16 values for group IA, 28 values for group IB and 47 values for group II. The remaining 3 values for group IA, 4 values for group IB and 3 values for group II were rejected as generating outlying residuals. The correlation between $\log \mathrm{M}_{0}$ and $\log \mathrm{E}_{\mathrm{R}}$, both in postblasting event groups and non-provoked events, is high $\left(R_{I}=0.907\right.$ and $\left.R_{I I}=0.781\right)$. There are also no significant differences between the $\log \mathrm{M}_{0}$ and $\log \mathrm{E}_{\mathrm{R}}$ correlations for sub-group IA and sub-group IB of post-blasting events $\left(\mathrm{R}_{\mathrm{IA}}=0.932\right.$ and $\left.\mathrm{R}_{\mathrm{IB}}=0.910\right)$. The results for all 101 events are consistent with those from other studies carried out for Rudna copper mine seismic data recorded for group of nonprovoked tremors (Gibowicz and Domański 2001; Domański and Gibowicz 2008).

Next, the spectral parameter estimated from the $\mathrm{E}_{0} / \mathrm{M}_{0}$ relation is an apparent stress. Usually, apparent stress is defined as the released energy per unit area of the fault plane and the displacement of the fault. If the P-wave contribution to the seismic energy is neglected, it is considered proportional to the stress drop (Snoke et al. 1983). Since the P-wave energy cannot be neglected in this case study, the apparent stress becomes an independent parameter describing the source properties (Gibowicz 1990; Gibowicz

Parameters of linear regression with standard errors for selected groups of events

\begin{tabular}{llll}
\hline & & $\mathrm{R}^{2}$ & $\mathrm{p}$ \\
\hline Group I & $\log \mathrm{E}_{0}=0.765 \pm 0.053 \log \mathrm{M}_{0}-3.348 \pm 0.632$ & 0.822 & $\mathrm{p}<10^{-16}$ \\
Subgroup IA & $\log \mathrm{E}_{0}=0.586 \pm 0.061 \log \mathrm{M}_{0}-1.513 \pm 0.729$ & 0.868 & $\mathrm{p}<10^{-6}$ \\
Subgroup IB & $\log \mathrm{E}_{0}=0.763 \pm 0.068 \log \mathrm{M}_{0}-3.725 \pm 0.816$ & 0.829 & $\mathrm{p}<10^{-10}$ \\
Group II & $\log \mathrm{E}_{0}=0.714 \pm 0.085 \log \mathrm{M}_{0}-3.374 \pm 1.037$ & 0.610 & $\mathrm{p}<10^{-10}$ \\
\hline
\end{tabular}


et al. 1991). Previous studies carried out with mining tremors show that apparent stress values can vary between $0.01 \mathrm{MPa}$ and $10 \mathrm{MPa}$ for very weak tremors that occurred in hard-rock gold mines with magnitudes down to $\mathrm{M}-4.5$ (e.g., Kwiatek et al. 2011) and from 0.001 to $0.15 \mathrm{MPa}$ for Rudna mine events with seismic moments $\mathrm{M}_{0}$ of $10^{11}-10^{14} \mathrm{Nm}$; these events occurred during a 10 years period from 1995 to 2005 in different panels (Domański and Gibowicz 2008). In this case study, $\sigma_{\mathrm{a}}$ varies between 0.0001 and $0.05 \mathrm{MPa}$ (Fig. 9) which is in good agreement with those parameters estimated in previous studies. The events within both sub-groups containing after-blasting tremors are characterized by the quite similar median values of $\sigma_{\mathrm{a}}\left(\mathrm{M} \sigma_{\mathrm{a}}\right.$ IA $=0.010 \mathrm{MPa}$ and $\mathrm{M \sigma}_{\mathrm{a}}$ IB $=0.011 \mathrm{MPa}$ ) while non-provoked events are characterized by a lower median value $\left(\mathrm{M} \sigma_{\mathrm{a} \text { II }}=0.005 \mathrm{MPa}\right)$ (Fig. 9). Higher apparent stress medians for provoked mining events can imply the high efficacy of blasting works and the partial stress reduction on the excavation level caused by explosive charge detonations.

Another investigated parameter, the $\mathrm{E}_{\mathrm{S}} / \mathrm{E}_{\mathrm{P}}$-ratio, is treated as an important indicator of possible failure processes, or energy distribution under different seismological conditions. It is general knowledge that the $E_{S} / E_{P}$ values for natural earthquakes are significantly higher than those ratios observed in anthropogenic seismicity including that produced by mining activities or fluid injection (e.g., Vavryčuk 2001; Castro and Ben-Zion 2013; Kwiatek and BenZion 2013). For natural earthquakes, this parameter is mostly linked with shear motions on faults, manifested by significantly stronger S-wave radiation. On the other hand, small values of the $E_{S} / E_{P}$ ratio can be correlated with tensile source processes attributed to non-double-couple parts of the focal mechanisms (Kwiatek et al. 2011). It has been shown that the $E_{S} /$ $E_{P}$ ratio in the case of mining-induced seismicity is rather small in comparison with that of natural earthquakes. This differences can be interpreted as a result of the influences of non-DC forces (Gibowicz and Kijko 1994; Gibowicz and Domański 2001; Kwiatek et al. 2011). We consider results for $E_{S} / E_{P^{-}}$ ratios determined for each group of tremors (Fig. 10).

In general, all seismic events are characterized by small $E_{S} / E_{P}$ which can suggest their non-DC nature.
There are no significant differences among groups I and II although for events that occurred just after detonations (sub-group IA), the ratios are smaller than those for the rest of the groups. Differences are also visible on example seismograms (Fig. 7 and electronical supplement ESM_1.pdf). The median value of the $E_{S} / E_{P}$ ratio in group IA is equal to 0.58 , whereas the medians for events that occurred during the waiting time and non-provoked events are similar and equal: 1.49 and 1.41, respectively. These observations can be partially explained by the influence of isotropic forces acting on tremors in sub-group IA. On the other hand, there is no additional evidence that events occurring within established waiting times (IB) are characterized by different ratios in comparison with 'common', non-provoked earthquakes.

Although most of the seismic sources analysed during this study were characterized by non-DC parts in the full MT, we have decided to also consider the static stress drop $\Delta \sigma$ as an additional indicator of possible differences among groups of events (Fig. 11). According to different studies, $\Delta \sigma$ could be influenced by various factors such as hypocentral depth (Baltay et al. 2011), rock strength and size of its damages (Feignier and Grasso 1991) or focal mechanisms (Kwiatek et al. 2015). According to presented results focal mechanism are features differentiating mining events analysed in our study. The stress drop was calculated assuming the circular model of Madariaga (1976), where $\Delta \sigma$ describes the average difference between the initial shear stress before an earthquake and the final stress levels. Typical values of the stress drops for mining tremors in different mining areas range from 0.1 to $10 \mathrm{MPa}$ (e.g., McGarr 1994; Gibowicz and Domański 2001; Yamada et al. 2007; Kwiatek et al. 2011) which in general is similar to the $\Delta \sigma$ observed for natural earthquakes. The results obtained for groups of events in this case study (Fig. 11) are in good agreement with previous estimate. The range of stress drops calculated for the group of post-blasting events (group I) varies between 0.15 and $13.50 \mathrm{MPa}$ and for non-provoked events (group II) from 0.12 to 19.54 MPa. Nevertheless, it is very difficult to show any specific differences between particular groups of events. This statement is also supported by the high scatter in obtained values for each group of events 
and median values of $\Delta \sigma$ which are comparatively the same for all three datasets $\left(\mathrm{M} \Delta \sigma_{\mathrm{IA}}=0.48 \mathrm{MPa}\right.$, $\mathrm{M} \Delta \sigma \quad$ IB $=0.42 \mathrm{MPa}$, and $\left.\mathrm{M} \Delta \sigma_{\text {II }}=0.44 \mathrm{MPa}\right)$ (Fig. 11b).

\section{Discussion and Conclusions}

In this study, we attempted to find any valuable seismological information to support the idea that the seismic sources of tremors that occurred after the blasting works are different from other spontaneous events which were not registered during the waiting time. Two seismic source analyses were employed to verified whether the source parameters estimated for events in the waiting time are different from the parameters obtained for spontaneous mining-induced tremors. While the source mechanisms of postblasting seismicity exhibit an interesting feature, namely, they are characterized by similar and statistically significant non-DC parts of the full MT, the spontaneous mining events are not similar in a sense of the full MT decomposition. All focal mechanisms of events which occurred during the waiting time period present similar explosive and tensile forces corresponding to horizontal cracks opening. These features could be partly caused by additional stress from rock fracturing due to explosion and/or stratify the roof rocks under exploitation stress changes. Similar positive non-DC sources are also observed in the group of non-provoked events what could be also justified by the roof rocks stratify mechanism. Nevertheless, the group of spontaneous events is very diverse in terms of focal mechanisms. It contains tremors of high shear motion contribution as well as compressive sources, which under mining conditions, could be explained by compressing pillars cracking. Due to the significant variety of results in the second, spontaneous group of events we are not able to define unequivocally differences between provoked and unprovoked mining seismicity. Furthermore in light of our results we believe that MT analyses for the purposes of blasting effectiveness evaluation should be rather considered statistically, on big groups of events, then locally for separate detonations. Additionally, using the source mechanisms only, we cannot define explicit and clear differences between events occurring immediately after blasting (i.e., max $30 \mathrm{~s}$ after detonations) and the group of events recorded during the waiting time. A similar conclusion can be derived when spectral parameters are considered. Nevertheless, according to our study, we can observe lower values of apparent stress in the group of spontaneous mining events. Higher apparent stress median values of post-blasting groups (group Ia and $\mathrm{Ib}$ ) could be an effect of variance in the stress field due to detonation of the explosive charge. On the other hand, the stress drop analysis does not show any significant differences between stress changes caused by post-blasting seismicity and those caused by non-provoked events. The second parameter indicating a distinction between post-blasting and spontaneous seismicity in Rudna copper mine is the $E_{S} / E_{P}$ ratio. The group of events occurring immediately after detonation (up to $30 \mathrm{~s}$ after detonation) exhibits lower values of the $E_{S} / E_{P}$ ratio than those for seismicity that occurs during the waiting time or for non-provoked events. In this case, reduction of $\mathrm{S}$ wave energy could be explained by higher explosive and tensile forces that acted in seismic sources provoked by rockburst active prevention. On the other hand higher contribution of P-waves, observed on the seismograms, may indicate explosive forces that were acting in analysed seismic sources. These results suggest that the $E_{S} / E_{P}$ ratio and apparent stress combined with MT analysis could be recommended as potential indicators of post-blasting seismicity and could be used in a blasting effectiveness evaluation. However, that estimation of detonation efficiency based on the presented parameters should be investigated under different mining conditions and according to the various blasting methods.

\section{Acknowledgements}

In-mine seismic data and technical information on the Rudna mine seismic network were obtained for this study with kind permission of KGHM Polska Miedź S.A. We wish to thank to PhD Dorota Olszewska for her help with statistical analysis done in this study. We are also thankful to two anonymous reviewers and to the editor for all helpful comments, which contributed to improving the manuscript. The work 
was partially supported within Polish National Science Centre project: PRELUDIUM 13 No. 2017/25/N/ST10/01759 (A. Caputa) as well as Institute of Geophysics Polish Academy of Sciences statutory activities No. 3841/E-41/S/2019 (E.Rudziński) granted by Ministry of Science and Higher Education of Poland.

Open Access This article is distributed under the terms of the Creative Commons Attribution 4.0 International License (http:// creativecommons.org/licenses/by/4.0/), which permits unrestricted use, distribution, and reproduction in any medium, provided you give appropriate credit to the original author(s) and the source, provide a link to the Creative Commons license, and indicate if changes were made.

Publisher's Note Springer Nature remains neutral with regard to jurisdictional claims in published maps and institutional affiliations.

\section{REFERENCES}

Baltay, A., Ide, S., Prieto, G., \& Beroza, G. (2011). Variability in earthquake stress drop and apparent stress. Geophysical Research Letters. https://doi.org/10.1029/2011GL046698.

Boatwright, J., \& Fletcher, J. B. (1984). The partition of radiated energy between $\mathrm{P}$ and $\mathrm{S}$ waves. Bulletin of the Seismological Society of America, 74(2), 361-376.

Boore, D. M., \& Boatwright, J. (1984). Average body-wave radiation coefficients. Bulletin of the Seismological Society of America, 74(5), 1615-1621.

Brune, J. (1970). Tectonic stress and the spectra of seismic shear waves from earthquakes. Journal of Geophysical Research, 75, 4997-5009.

Brune, J. N. (1971). Seismic sources, fault plane studies and tectonics. EOS, 52, 178-187.

Butra, J., \& Kudełko, J. (2011). Rockburst hazard evaluation and prevention methods in Polish copper mines. Cuprum, 61(4), 5-20.

Caputa, A., Talaga, A., \& Rudziński, Ł. (2015). Analysis of postblasting source mechanisms of mining-induced seismic events in Rudna copper mine. Poland: Contemporary Trends in Geoscience. https://doi.org/10.1515/ctg-2015-0003.

Castro, R. R., \& Ben-Zion, Y. (2013). Potential signatures of damage-related radiation from aftershocks of the 4 April 2010 (Mw 7.2) El Mayor-Cucapah earthquake, Baja California, México. Bulletin of the Seismological Society of America. https:// doi.org/10.1785/0120120163.

Domański, B., \& Gibowicz, S. (2008). Comparison of source parameters estimated in the frequency and time domains for seismic events at the Rudna Copper Mine. Poland: Acta Geophysica. https://doi.org/10.2478/s11600-008-0014-1.
Dreger, D. S., Ford, S. R., \& Walter, W. R. (2008). Source analysis of the Crandall Canyon, Utah, mine collapse. Science. https://doi. org/10.1126/science.1157392.

Dubiński, J., \& Konopko, W. (2000). Tapania, ocena, prognoza, zwalczanie. Katowice: GIG.

Feignier, B., \& Grasso, J.-R. (1991). Relation between seismic source parameters and mechanical properties of rocks: A case study. Pure and Applied Geophysics. https://doi.org/10.1007/ BF00876987.

Gibowicz, S. J. (1990). Seismicity induced by mining. Advances in Geophysics, 32, 1-74.

Gibowicz, S. J., \& Domański, B. (2001). Spektra sejsmiczne i parametry ognisk wstrząsów górniczych. In J. Dubiński, Z. Pilecki, \& W. M. Zuberek (Eds.), Badania sejsmiczne $w$ kopalniach (pp. 35-47). Kraków: IGSMiE PAN.

Gibowicz, S. J., \& Kijko, A. (1994). An introduction to mining seismology. San Diego: Academic. https://doi.org/10.1017/ CBO9781107415324.004.

Gibowicz, S. J., Young, R. P., Talebi, S., \& Rawlence, D. J. (1991). Source parameters of seismic events at the underground in Manitoba, Canada: Scaling relations for events with moment magnitude smaller than -2. Bulletin of the Seismological Society of America, 81(4), 1157-1182.

Gogolewska, A. (2010). Prowokowanie wstrząsów w rejonie zaburzeń tektonicznych w polu eksploatacyjnym G-7/5. Prace Naukowe Instyutu Górnictwa Politechniki Wroctawskiej, 38(131), 50-51.

Gogolewska, A., \& Biernat, M. (2005). Aktywna profilaktyka tạpaniowa stosowana w wybranym oddziale eksploatacyjnym O/ZG „Rudna” KGHM Polska Miedź S.A. w latach 2001-2003. Prace Naukowe Instyutu Górnictwa Politechniki Wroctawskiej, 31(113), 50-51.

Gogolewska, A., \& Michalak, M. (2009). Parametry klasyfikacyjne skał stropowych i aktywność sejsmiczna w O/ZG "Lubin". Prace Naukowe GIG "Górnictwo i Środowisko", 36(128), 71-102.

Goszcz, A. (1999). Elementy mechaniki skat oraz tapania $w$ polskich kopalniach węla i miedzi. Kraków: IGSMiE PAN.

Hanks, T. C., \& Kanamori, H. (1979). A moment magnitude scale. Journal of Geophysical Research B: Solid Earth. https://doi.org/ 10.1029/JB084iB05p02348.

Hasegawa, H. S., Wetmiller, R. J., \& Gendzwill, D. J. (1989). Induced seismicity in mines in Canada-An overview. Pure and Applied Geophysics. https://doi.org/10.1007/BF00874518.

Hinzen, K. G. (1998). Comparison of seismic and explosive energy in five smooth blasting test rounds. International Journal of Rock Mechanics and Mining Sciences. https://doi.org/10.1016/S01489062(98)00159-4.

Hollander, M., \& Wolfe, D. A. (1973). Nonparametric statistical methods. New York: Wiley.

Hudson, J. A., Pearce, R. G., \& Rogers, R. M. (1989). Source type plot for inversion of the moment tensor. Journal of Geophysical Research, 94(B1), 765-774.

Jost, M. L., \& Herrmann, R. B. (1989). A studen's guide to and review of moment tensors. Seismological Research Letters, 60(2), 37-57.

Kłeczek, Z. (2004). Grupowe strzelanie przodków jako element profilaktyki tạpaniowej w kopalniach rud miedzi LGOM. Górnictwo i Geoinżynieria, 28(3/1), 153-159.

Konicek, P., Soucek, K., Stas, L., \& Singh, R. (2013). Long-hole destress blasting for rockburst control during deep underground 
coal mining. International Journal of Rock Mechanics and Mining Sciences. https://doi.org/10.1016/j.ijrmms.2013.02.001.

Koziarz, E., \& Szłapka, M. (2010). Kierunki dalszego rozwoju informatycznego systemu do bezpośredniej lokalizacji zjawisk dynamicznych w O/ZG „Rudna” KGHM „Polska Miedź” SA. Wiadomości Górnicze, 3, 159-174.

Król, M. (1998). Zastosowanie tensora momentu sejsmicznego oraz analizy widmowej fali sejsmicznej do badani ognisk wstrzasów z rejonu kopalni Polkowice-Sieroszowice. Warsaw: Polish Academy of Science.

Kwiatek, G., \& Ben-Zion, Y. (2013). Assessment of P and S wave energy radiated from very small shear-tensile seismic events in a deep South African mine. Journal of Geophysical Research: Solid Earth. https://doi.org/10.1002/jgrb.50274.

Kwiatek, G., Martínez-Garzón, P., \& Bohnhoff, M. (2016). HybridMT: A MATLAB/shell environment package for seismic moment tensor inversion and refinement. Seismological Research Letters. https://doi.org/10.1785/0220150251.

Kwiatek, G., Martínez-Garzõn, P., Dresen, G., Bohnhoff, M., Sone, H., \& Hartline, C. (2015). Effects of long-term fluid injection on induced seismicity parameters and maximum magnitude in northwestern part of the Geysers geothermal field. Journal of Geophysical Research: Solid Earth. https://doi.org/10.1002/ 2015JB012362.

Kwiatek, G., Plenkers, K., \& Dresen, G. (2011). Source parameters of picoseismicity recorded at Mponeng deep gold mine, South Africa: Implications for scaling relations. Bulletin of the Seismological Society of America. https://doi.org/10.1785/ 0120110094.

Lasocki, S. (2005). Probabilistic analysis of seismic hazard posed by mining induced. In Y. Potvin \& M. Hudyma (Eds.), 6th int. symp. on rockburst and seismicity in mines, 9-11 March 2005 (pp. 151-156). Nedlands: Australian Centre for Geomechanics.

Lasocki, S., Orlecka-Sikora, B., Mutke, G., Pytel, W., Rudziński, Ł., Markowski, P., \& Piasecki, P. (2017). A catastrophic event in Rudna copper-ore mine in Poland on 29 November, 2016: What, how and why. In J. A. Vallejos (Ed.), 9th int. symp. on rockbursts and seismicity in mines (pp. 316-324). Santiago, Chile: Editec S.A.

Lizurek, G., Rudziński, Ł., \& Plesiewicz, B. (2015). Mining induced seismic event on an inactive fault. Acta Geophysica. https://doi.org/10.2478/s11600-014-0249-y.

Lizurek, G., \& Wiejacz, P. (2011). Geophysics in mining and environmental protection: Moment tensor solution and physical parameters of selected recent seismic events at Rudna Copper Mine. In A. F. Idziak \& R. Dubiel (Eds.), GeoPlanet: Earth and planetary sciences. https://doi.org/10.1007/978-3-642-19097-1_ 2.

Madariaga, R. (1976). Dynamics of an expanding circular fault. Bulletin of the Seismological Society of America, 66(3), 639-666.
Madariaga, R., \& Ruiz, S. (2016). Earthquake dynamics on circular faults: A review 1970-2015. Journal of Seismology. https://doi. org/10.1007/s10950-016-9590-8.

McGarr, A. (1994). Some comparisons between mining-induced and laboratory earthquakes. Pure and Applied Geophysics. https://doi.org/10.1007/BF00876051.

Rudziński, Ł., Cesca, S., \& Lizurek, G. (2016). Complex rupture process of the 19 March 2013, Rudna Mine (Poland) induced seismic event and collapse in the light of local and regional moment tensor inversion. Seismological Research Letters. https://doi.org/10.1785/0220150150.

Rudziński, Ł., \& Dębski, W. (2011). Extending the double-difference location technique to mining applications part I: Numerical study. Acta Geophysica. https://doi.org/10.2478/s11600-0110021-5.

Rudziński, Ł., \& Dineva, S. (2017). Towards energy magnitude for mining induced seismicity. In J. A. Vallejos (Ed.), 9th int. symp. on rockbursts and seismicity in mines, Santiago (pp. 189-195).

Rudziński, Ł., Mirek, J., \& Lizurek, G. (2017). Identification of seismic doublets occurred on Rudna mine. Poland: Acta Geophysica. https://doi.org/10.1007/s11600-017-0034-9.

Sanchidrián, J. A., Segarra, P., \& López, L. M. (2007). Energy components in rock blasting. International Journal of Rock Mechanics and Mining Sciences. https://doi.org/10.1016/j. ijrmms.2006.05.002.

Snoke, J. A., Linde, A. T., \& Sacks, I. S. (1983). Apparent stress: An estimate of the stress drop. Bulletin of the Seismological Society of America, 73(2), 339-348.

Vavryčuk, V. (2001). Inversion for parameters of tensile earthquake. Journal of Geophysical Research. https://doi.org/10.1029/ 2001JB000372.

Waczur, J., \& Zaczek, F. (2004). Zmienność fizykomechanicznych własności skał stropowych złoża rud miedzi Kopalni "Rudna". Prace Naukowe Instyutu Górnictwa Politechniki Wroctawskiej, 30(106), 217-224.

Wojtecki, Ł., Mendecki, M. J., \& Zuberek, W. M. (2017). Determination of destress blasting effectiveness using seismic source parameters. Rock Mechanics and Rock Engineering. https://doi. org/10.1007/s00603-017-1297-9.

Wojtecki, Ł., Mendecki, M. J., Zuberek, W. M., \& Knopik, M. (2016). An attempt to determine the seismic moment tensor of tremors induced by destress blasting in a coal seam. International Journal of Rock Mechanics and Mining Sciences, 83, 162-169. https://doi.org/10.1016/j.ijrmms.2016.01.002.

Yamada, T., Mori, J. J., Ide, S., et al. (2007). Stress drops and radiated seismic energies of microearthquakes in a South African gold mine. Journal of Geophysical Research: Solid Earth. https://doi.org/10.1029/2006JB004553. 